Bull. Chem. Soc. Ethiop. 2020, 34(1), 75-82.

ISSN 1011-3924

(C) 2020 Chemical Society of Ethiopia and The Authors

Printed in Ethiopia

DOI: https://dx.doi.org/10.4314/bcse.v34i1.7

\title{
BIODIESEL PRODUCTION FROM VITEX DONIANA (BLACK PLUM) SEED OIL VIA A TWO-STEP CATALYZED TRANSESTERIFICATION
}

\author{
Gloria Ihuoma Ndukwe* and Anselem Tochukwu Ugboaja
}

Department of Chemistry, Rivers State University, Nkpolu-Oroworukwo, Port Harcourt, Nigeria

(Received July 4, 2019; Revised December 23, 2019; Accepted January 2, 2020)

\begin{abstract}
Increasing global energy demands have led to increased search for alternative sources of fuel. Due to its similarities with petroleum-based diesel, biodiesel arose as a potential replacement for diesel. In this study, biodiesel was produced from the seed oil of Vitex doniana (black plum) using a two-step catalyzed transesterification method. The biodiesel produced was also characterized. Physico-chemical analyses carried out on the produced biodiesel gave strong indication that it can serve as an alternative feedstock, having recorded a comparable flash point of $110{ }^{\circ} \mathrm{C}$ to American Society of Testing Materials and European Committee for Standardization standards; though kinematic viscosity measurements showed biodiesel products of relatively high viscosity which has the tendency to leave deposits on combustion. Spectroscopic analyses indicated successful transesterification with $95-98 \%$ biodiesel yield.
\end{abstract}

KEY WORDS: Vitex doniana, Black plum, Transesterification, Biodiesel, Two-step catalyzed

\section{INTRODUCTION}

The increase in global demand for energy has given rise to increased search for alternative sources of fuel. There has been a steady rise in energy needs which saw an expansion by $30 \%$ of energy generation [1]. The share of renewable energy sources grew by nearly $1 \%$ to almost $25 \%$ in 2017 [2]. These efforts in renewal energy sources include but not limited to solar, wind, hydro and more recently harvesting, liquefaction and conversion of atmospheric carbon dioxide to fuel [3]. Biodiesel is one of such effort that has gained traction as it can be made from varied sources. Due to the widespread availability of biomass resources, biomass-based fuel technology can potentially employ more people than fossil fuel-based technology [4]. A variety of fuels can be produced from biomass resources including liquid fuels, such as ethanol, methanol, biodiesel and gaseous fuels, such as hydrogen and methane. Biofuels are primarily used in vehicles but can also be used in engines or fuel cells for electricity generation.

Biodiesel has been described as diesel fuel based on animal or vegetable sources [5]. It is a biofuel consisting of long chain mono-alkyl esters [6]; an alternative to conventional or fossil diesel, with most biodiesel presently being sourced from waste vegetable oil and oilseed crops. Biodiesel has been used in the pure form (B100) or blended with petroleum diesel [7]. Most of the common blends include B2 (2\% biodiesel, 98\% petrodiesel), B5 (5\% biodiesel, 95\% petrodiesel) or B20 ( $20 \%$ biodiesel, $80 \%$ petrodiesel). Pure biodiesel contains less energy on a volumetric basis than petroleum diesel, as such lower-level blends can be used in current engines without modifications [8]. B20 provides similar fuel economy, horsepower, torque, and haulage rates as diesel fuel. In addition to having superior lubricity, it has the highest British Thermal Unit (BTU) content of any alternative fuel [7].

Transesterification is a catalyzed chemical reaction involving the conversion of a carboxylic acid ester into a different carboxylic acid ester. It is a process of exchanging the organic alkyl groups of plant oil - an ester with the methyl group of methyl alcohol. When an alcohol usually methanol comes in contact with free fatty acids, they bond to form a biodiesel [9]. Higher alcohols such as ethanol, isopropanol and butanol can also be used to produce biodiesel.

*Corresponding author. E-mail: gloria.ndukwe@ust.edu.ng

This work is licensed under the Creative Commons Attribution 4.0 International License 
The seed of Vitex doniana also known as black plum could be a potential source of biodiesel. Vitex doniana is native to and largely found in tropical Africa. It belongs to the Verbenaceae family and it is a medium-sized deciduous tree, $8-18 \mathrm{~m}$ high, with a heavy rounded crown and a clear bole up to $5 \mathrm{~m}$. The bark is rough, pale brown or greyish-white, rather smooth with narrow vertical fissures. The bases of old trees have oblong scales. The fruit (Figure 1) is about $3 \mathrm{~cm}$ long; green when young, turning purplish-black on ripening and with a starchy black pulp. Each fruit contains one hard, conical seed (Figure 2), 1.5-2 cm long, 1-1.2 cm wide [10]. Vitex species generally exhibit hermaphroditism, where both functional male and female organs are in the same flower [11]. Reported works on Vitex doniana are all based on biological activities of different parts of the plant [12-14].

This research is aimed at looking at the seed of Vitex doniana which is considered an inedible and waste material, as an alternative feedstock in biodiesel production.

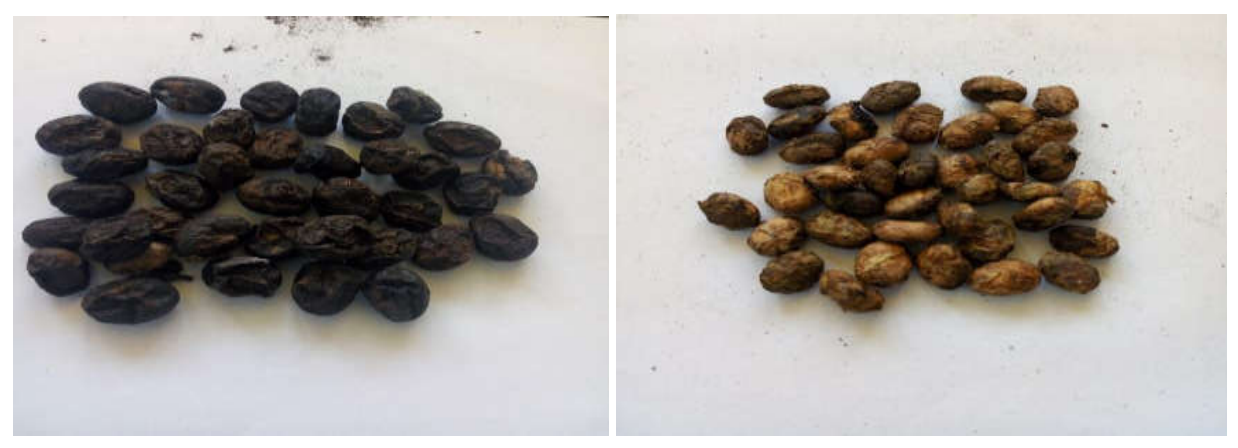

Figure 1. Vitex doniana dry fruit.

Figure 2. Vitex doniana dry seed.

\section{EXPERIMENTAL}

Reagents

The following are the chemicals used during this work: absolute ethanol, absolute methanol, conc. sulfuric acid, potassium hydroxide, glacial acetic acid, iodine, potassium iodide, sodium thiosulfate, chloroform, isopropyl alcohol (all Sigma Aldrich) and re-distilled n-hexane.

\section{Instrumentation}

The instruments employed for analyses in this work include; Perkin-Elmer Fourier TransformInfra Red spectrum 2 with serial number 97529, Viscometer bath (Stanhope SETA) maintained at $40{ }^{\circ} \mathrm{C}$, Penski Martens closed cup flash point tester, gas chromatograph-flame ionization detection (GC-FID) (HP6890) column type HP INNOWax with carrier gas as nitrogen gas, Hinotek SYD-510D pour and cloud point tester, water bath, rotary evaporator and analytical balance. The infrared spectra of Vitex doniana seed oil and the subsequent biodiesels were measured using a PerkinElmer ${ }^{\circledR}$ Spectrum ${ }^{\mathrm{TM}}$ Two FT-IR spectrometer. To obtain the best contact time with the crystal and the background spectrum, the samples were injected into the empty accessory. Approximately $5 \mathrm{~min}$ was required for spectral collection which were recorded within a range of $4000-550 \mathrm{~cm}^{-1}$ with a $4 \mathrm{~cm}^{-1}$ resolution. In accordance with European Union (EU) norm EN 14103 [15], using a GC-FID HP6890 apparatus (Agilent Technologies, USA) equipped with data acquisition software HP Chemstation Rev.A.09.01 (1206), gas chromatography analyses were performed on the biodiesels. To accomplish separation, $15 \mathrm{~m}$ long HP-INNOWAX capillary column $(30 \mathrm{~m} \mathrm{X} 0.25 \mathrm{~mm}$ and $0.25 \mu \mathrm{m}$ film 
thickness) and a constant hydrogen flow rate of 22 psi were used. With an injector temperature of $250{ }^{\circ} \mathrm{C}$, samples $(1 \mu \mathrm{L})$ were injected in a split ratio of $20: 1$. The oven started with an initial temperature of $12{ }^{\circ} \mathrm{C}$ and was followed by an increase in temperature up to $15^{\circ} \mathrm{C}$.

\section{Plant material}

Fruit samples of Vitex doniana were purchased from a fruit market in Port Harcourt, Rivers State, Nigeria and identified by matching against the database of the Plant for a Future organization (PFAF) [16]. The fruits were peeled, the seeds extracted and air dried. The seed $(3.012 \mathrm{~kg})$ were pulverized to increase the surface area for subsequent extraction of oil.

\section{Extraction of oil}

The $3.012 \mathrm{~kg}$ of pulverized $V$. doniana seeds was soaked with $2.5 \mathrm{~L}$ n-hexane in an aspirator bottle for 24 hours. It was then filtered and concentrated using a rotary evaporator. The extraction process was repeated 6 times with fresh n-hexane each time [17]. The extracted oil was weighed, and the percentage yield calculated.

\section{Acid value and percentage free fatty acid (\% FFA) (ASTM D664)}

Vitex doniana seed oil $(0.5 \mathrm{~g})$ was weighed into a dry conical flask and $20 \mathrm{~mL}$ of isopropyl alcohol (IPA) added to it. 3 drops of phenolphthalein indicator was added and mixed properly. The solution was titrated with $0.1 \mathrm{~N}$ potassium hydroxide until a pink colour that stayed for $15 \mathrm{~s}$ was observed. The volume of $\mathrm{KOH}$ used was recorded as $\mathrm{A}$. The procedure was repeated for the blank starting with IPA and volume of $\mathrm{KOH}$ used recorded as B. Acid value and percentage free fatty acid were obtained using equations 1 and 2, respectively [18].

Acid value $=\frac{(\mathrm{A}-\mathrm{B}) \times \text { Normality of the base } \times 56.1 \mathrm{~g}}{\text { Weight of oil used }(\mathrm{g})}$

$\%$ FFA $=\frac{(\mathrm{A}-\mathrm{B}) \times \text { Normality of the base } \times 28.2 \mathrm{~g}}{\text { Weight of oil used }(\mathrm{g})}$

Iodine value (Association of Official Analytical Chemists (AOAC) Official Methods Cd 11-92)

The oil of $V$. doniana seed $(0.5 \mathrm{~g})$ was weighed and dissolved in a conical flask with $20 \mathrm{~mL}$ of chloroform. $20 \mathrm{~mL}$ of $\mathrm{KI}$ solution was added followed by $100 \mathrm{~mL}$ of distilled water. The resulting solution was placed in the dark for $30 \mathrm{~min}$. The solution was titrated with standardized $0.1 \mathrm{M}$ sodium thiosulfate using $1 \mathrm{~mL}$ of starch solution as indicator and stirred continuously till the end point was achieved $\left(\mathrm{V}_{1}\right)$. A blank $\left(\mathrm{V}_{2}\right)$ was carried out starting with $20 \mathrm{~mL}$ of chloroform. Solution turned to blue black precipitate and then to colourless. Iodine value was calculated using equation 3 [19].

Iodine value $=\frac{\left(\mathrm{V}_{2}-\mathrm{V}_{1}\right) \times \text { Normality of } \mathrm{Na}_{2} \mathrm{~S}_{2} \mathrm{O}_{3} \times 12.69 \mathrm{~g}}{\text { Weight of oil used }(\mathrm{g})}$

Saponification value (AOAC Official Methods Cd 3-25)

Vitex doniana seed oil $(0.25 \mathrm{~g})$ was weighed into a round bottomed flask and dissolved with 10 $\mathrm{mL}$ of $0.5 \mathrm{~N}$ ethanolic solution of potassium hydroxide and the solution was refluxed to ensure perfect dissolution. The solution was allowed to cool and phenolphthalein ( 3 drops) added. The solution was titrated with $0.5 \mathrm{~N} \mathrm{HCl}\left(\mathrm{V}_{1}\right)$. A blank $\left(\mathrm{V}_{2}\right)$ was carried out as well. Thus, saponification value was calculated using equation 4 [19].

Saponification value $=\frac{\left(\mathrm{V}_{2}-\mathrm{V}_{1}\right) \times \text { Normality of } \mathrm{HCl} \times 56.1 \mathrm{~g}}{\text { Weight of oil used }(\mathrm{g})}$ 
Peroxide value (AOAC official Methods Cd 8b-90)

The oil of Vitex doniana seed $(0.5 \mathrm{~g})$ was weighed into a conical flask and dissolved with $25 \mathrm{~mL}$ mixture of acetic acid and chloroform ( 2 volume of glacial acetic acid and 1 volume of chloroform). $1 \mathrm{~mL}$ of saturated solution of potassium iodide was added, followed closely by the addition of $7.5 \mathrm{~mL}$ of distilled water. The solution was titrated with $0.1 \mathrm{~N}$ sodium thiosulfate until the yellow color disappeared. Starch indicator $(0.5 \mathrm{~mL})$ was added to the solution and the titration continued to end point $\left(\mathrm{V}_{1}\right)$. A blank was carried out as well. Peroxide value was calculated using equation 5 [19].

Peroxide value (Milleqv. peroxide/kg $=\frac{\left(\mathrm{V}_{2}-\mathrm{V}_{1}\right) \times \text { Normality of } \mathrm{Na}_{2} \mathrm{~S}_{2} \mathrm{O}_{3} \times 1000}{\text { Weight of oil used }(\mathrm{g})}$

Acid pretreatment (acid catalyzed esterification)

Vitex doniana seed oil $(300 \mathrm{~mL})$ was heated on a heating mantle at $55^{\circ} \mathrm{C}$. A mixture of $6 \mathrm{~mL}$ of concentrated sulfuric acid and $20 \mathrm{~mL}$ of methanol was introduced into a round bottomed flask containing the oil. The mixture was stoppered, placed on a thermostated magnetic stirrer maintained at $400 \mathrm{rpm}$ and refluxed for 1 hour. The mixture was then poured into a separating funnel and allowed to stand for 2 hours. The lower layer consisting of aqueous phase was tapped off. The same procedure was repeated using ethanol [4].

\section{Base catalyzed transesterification}

The pretreated $V$. doniana oil $(200 \mathrm{~mL}$ of oil pretreated with methanol) was measured and poured into the round bottomed flask which was immersed in a water bath set at $55{ }^{\circ} \mathrm{C}$ and allowed to heat up until the temperature of the water bath was attained. $\mathrm{KOH}(1.006 \mathrm{~g})$ was weighed and added to a conical flask containing $20 \mathrm{~mL}$ of methanol and swirled gently until the $\mathrm{KOH}$ pellet dissolve, thereby forming methoxide solution. The methoxide solution was added to the heated oil and refluxed for 1 hour at a temperature maintained at $55{ }^{\circ} \mathrm{C}$. The mixture was poured into a separating funnel and allowed to stand for 1 hour for separation to take place. The lower layer (glycerol) was tapped off and the upper layer (biodiesel) was washed 6 times with warm distilled water. This same process was repeated for the oil that was pretreated with ethanol, in this case, ethanol was used instead of methanol. The volume and weight of obtained biodiesel were measured and recorded.

Density measurement (ASTM D445-12)

An empty beaker was weighed using an analytical weighing balance. $30 \mathrm{~mL}$ of produced biodiesel was then poured into the beaker, and the combined weight measured. The difference between the weight of the beaker plus biodiesel and that of the empty beaker was obtained and recorded as the weight of the oil. The density was obtained by taking the ratio of the weight of the biodiesel and its volume [18].

Density of biodiesel $=\frac{\text { Weight of measured biodiesel }}{\text { Volume of measured biodiesel }}$

Kinematic viscosity measurement (ASTM D445)

Produced biodiesel $(10 \mathrm{~mL})$ was poured into a viscometer tube. The tube was then immersed into a viscometer bath maintained at $40{ }^{\circ} \mathrm{C}$. The oil in the tube was sucked up to the upper limit mark using a suction pump and allowed to drop under gravity. A stopwatch was started and the set up monitored till the oil got to the lower limit of the tube and the watch stopped. The time was recorded, and the procedure repeated twice. The kinematic viscosity was calculated using equation 7 [18]. 
$\mathrm{KV} @ 40^{\circ} \mathrm{C}\left(\mathrm{mm}^{2} / \mathrm{s}\right)=$ Time $(\mathrm{s}) \times$ Tube constant

\section{Flash point (ASTM D93)}

The Pensky-Martens closed cup apparatus was used to obtain the flash points of the biodiesel produced. Produced biodiesel was poured into the brass cup to touch the prescribed mark inside the cup and then gently placed into its position until it locked. A thermometer was placed inside through the provided opening. At intervals, lighted flame was passed through the sample in the cup to check for flash, while temperature was being monitored. The temperature at the first distinct flash was taken and recorded. This gave the closed flash point of the biodiesel [18].

Pour point (ASTM D6892-03, 2014)

The biodiesel in a test jar with a thermometer clamped to it was cooled inside a constant temperature cooling bath, as it cooled it formed wax crystals. The test jar was removed at every degree drop in temperature and tilted to check the surface movement. When the surface did not flow for $5 \mathrm{~s}$, the temperature was recorded [18].

\section{RESULTS AND DISCUSSION}

Table 1 summarizes the physico-chemical properties of Vitex doniana seed oil. Vitex doniana seed recorded a moderately high oil yield of $18.5 \%(640 \mathrm{~mL})$, with acid value of $4.08 \mathrm{mg}$ $\mathrm{KOH} / \mathrm{g}$ and \% FFA of 2.05 . This oil was pre-treated to reduce the acid value to $1.006 \mathrm{mg}$ $\mathrm{KOH} / \mathrm{g}$ which is within the permissible limit. High amount of FFA can lead to emulsification and present great difficulty during separation of the biodiesel from glycerol and during washing [4]. Acidity has been found to come from fatty acid composition of the oil unlike that of fossil diesel fuel which comes from sulfur content [20].

Table 1. Physicochemical properties of Vitex doniana seed oil.

\begin{tabular}{|l|l|l|}
\hline Property & Unit & Value \\
\hline Color & & Orange \\
\hline Appearance & & Liquid \\
\hline$\%$ Yield & $\%$ & 18.5 \\
\hline Saponification value & $\mathrm{Mg} \mathrm{KOH} / \mathrm{g}$ & 160 \\
\hline Peroxide value & $\mathrm{Millieqv}$ peroxide $/ \mathrm{kg}$ & 137 \\
\hline Iodine value & $\mathrm{g} \mathrm{I} / 100 \mathrm{~g}$ of oil & 118 \\
\hline Density @ $15^{\circ} \mathrm{C}$ & $\mathrm{g} / \mathrm{cm}^{3}$ & 0.8713 \\
\hline Pour point & ${ }^{\circ} \mathrm{C}$ & 4 \\
\hline Acid value & $\mathrm{Mg} \mathrm{KOH} / \mathrm{g}$ & 4.08 \\
\hline$\%$ FFA & $\%$ & 2.05 \\
\hline
\end{tabular}

Table 2 outlines the physico-chemical properties of biodiesels produced from Vitex doniana seed oil as it compares with European biodiesel standard EN 14214:2008 and American biodiesel standard as contained in ASTM D6751-07b. Transesterification of the Vitex doniana seed oil recorded high conversion percentages of $95 \%$ and $98 \%$ with potassium ethoxide and potassium methoxide, respectively. This implies that almost all the starting oil was transesterified. With reference to European standards for biodiesel EN 14214:2008 (0.86-0.9) and comparing with standard for petrodiesel EN 590:1999 (0.82-0.845), the densities of the biodiesels which are 0.8339 and 0.8917 are within specifications.

It has been suggested that low viscosity fuel produce very subtle spray and cannot get into the combustion cylinder thus forming the fuel rich zone which leads to the formation of soot [21]. On the other hand, higher viscosity turns atomized fuel into larger droplets with high 
momentum and has a tendency to collide with the cylinder wall relatively. This leads to an increase in deposits and fuel emissions [21, 22]. Thus, from the kinematic viscosity at $40{ }^{\circ} \mathrm{C}$ results as presented in Table 2 showing $12 \mathrm{~mm}^{2} / \mathrm{s}$ for biodiesel produced with ethoxide and biodiesel produced with methoxide as $11.72 \mathrm{~mm}^{2} / \mathrm{s}$; it is clear that the biodiesels produced from Vitex doniana are way above the EN 14214:2008 and ASTM D6751-07b ranges of 3.5-5 mm²/s and $1.9-6 \mathrm{~mm}^{2} / \mathrm{s}$, respectively, and may have the tendency to leave deposits on combustion.

The flash points of biodiesels were $100{ }^{\circ} \mathrm{C}$ for biodiesel produced with ethoxide and $104{ }^{\circ} \mathrm{C}$ for biodiesel produced with methoxide (Table 2) which are within the standard range for biodiesel cited. The values were higher than that of petrodiesel $\left(55^{\circ} \mathrm{C}\right)$ and this makes them more stable to fire. Flash point has nothing to do with engine performance but rather fuel handling and storage [23], the result obtained allows the biodiesels from Vitex doniana seed oil to be classified as non-hazardous under National Fire Protection Association Codes. The obtained flash points suggest that the biodiesels are not highly flammable but would require safety precautions like any fuel during usage, storage and transportation [24].

Table 2. Physicochemical properties of biodiesels from $V$. doniana seed oil.

\begin{tabular}{|c|c|c|c|c|c|c|}
\hline \multirow[t]{2}{*}{ Property } & \multirow[t]{2}{*}{ Unit } & \multirow{2}{*}{$\begin{array}{l}\text { Biodiesel } \\
\text { produced with } \\
\text { ethoxide }\end{array}$} & \multirow{2}{*}{$\begin{array}{l}\text { Biodiesel } \\
\text { produced with } \\
\text { methoxide }\end{array}$} & \multicolumn{3}{|l|}{ Standards } \\
\hline & & & & $\begin{array}{l}\text { Biodiesel } \\
\text { EN14214: } 2008\end{array}$ & $\begin{array}{l}\text { ASTM } \\
\text { D6751-07b }\end{array}$ & $\begin{array}{l}\text { Petrodiesel } \\
\text { EN 590:1999 }\end{array}$ \\
\hline Color & & Brownish red & Orange & & & \\
\hline Appearance & & Liquid & Liquid & & & \\
\hline$\%$ Yield & $\%$ & 95 & 98 & & & \\
\hline Flash point & ${ }^{\circ} \mathrm{C}$ & 100 & 104 & $\geq 101$ & $\geq 93$ & 55 \\
\hline $\mathrm{KV} @ 40^{\circ} \mathrm{C}$ & $\mathrm{mm}^{2} / \mathrm{s}$ & 12.00 & 11.72 & $3.5-5$ & $1.9-6.0$ & $2.0-4.5$ \\
\hline Density@15 $15^{\circ} \mathrm{C}$ & $\mathrm{g} / \mathrm{cm}^{3}$ & 0.8339 & 0.8917 & $0.86-0.90$ & & $0.820-0.845$ \\
\hline Pour point & ${ }^{\circ} \mathrm{C}$ & 12 & 12 & & $-5-10$ & $5.6-11.1$ \\
\hline
\end{tabular}

Table 3 outlines the fatty acid alkyl ester composition of the biodiesels. The results of GCFID technique carried out on the biodiesels show that the products from Vitex doniana seed oil has high percentage (above $40 \%$ ) of oleic acid alkyl esters, a mono unsaturated FAME; followed closely by linoleic acid alkyl esters (28-29\%) in addition to other fatty acid alkyl esters. The degree of unsaturation of biodiesel fuels has effects on engine emissions via its effect on the cetane number and adiabatic flame temperature while engine performance is not significantly affected by the type of biodiesel fuel nor its degree of unsaturation [25].

Table 3. GC-FID result of biodiesels produced from Vitex doniana seeds oil.

\begin{tabular}{|l|l|l|l|l|}
\hline $\begin{array}{l}\text { Retention time } \\
(\mathrm{min})\end{array}$ & $\begin{array}{l}\text { Compound (biodiesel } \\
\text { produced with methoxide) }\end{array}$ & $\begin{array}{l}\text { Compound (biodiesel } \\
\text { produced with ethoxide) }\end{array}$ & $\begin{array}{l}\text { Concentration } \\
(\%)\end{array}$ & $\begin{array}{l}\text { No. of } \\
\text { C-atoms }\end{array}$ \\
\hline 16.044 & Palmitic acid methyl ester & & 18.948 & C 16:0 \\
\hline 16.251 & & Palmitic acid ethyl ester & 16.452 & C 16:0 \\
\hline 16.605 & Palmitoleic methyl ester & & 1.232 & C 16:1 \\
\hline 16.921 & & Palmitoleic acid ethyl ester & 1.454 & C 16:1 \\
\hline 18.159 & & Stearic acid ethyl ester & 4.738 & C $18: 0$ \\
\hline 18.942 & Oleic acid methyl ester & & 42.898 & C $18: 1$ \\
\hline 19.032 & & Oleic acid ethyl ester & 43.249 & C $18: 1$ \\
\hline 19.526 & Linoleic acid methyl ester & & 28.054 & C $18: 2$ \\
\hline 19.573 & & Linoleic acid ethyl ester & 29.702 & C $18: 2$ \\
\hline 20.658 & Linolenic acid methyl ester & & 1.431 & C $18: 3$ \\
\hline
\end{tabular}

In Table 4, the FT-IR absorption peaks and their corresponding functional groups are presented for the oil and biodiesels. When compared to the FT-IR result obtained for the oil, the biodiesels showed strong absorption peak at $1750 \mathrm{~cm}^{-1}$ just as seen in the oil. This agrees with reported absorption attributed to stretching of $\mathrm{C}=\mathrm{O}$, characteristic of esters. Another prominent 
peak was observed at $2900 \mathrm{~cm}^{-1}$ attributable to the symmetrical $\mathrm{C}-\mathrm{H}$ stretching vibration in esters, as well as strong absorption at $1480 \mathrm{~cm}^{-1}$ attributed to $\mathrm{CH}_{2}$ bending vibration. Esters have two characteristically strong absorption bands arising from carbonyl $(\mathrm{C}=\mathrm{O})$ around $1750-1730$ $\mathrm{cm}^{-1}$ and that of C-O (antisymmetric axial stretching and asymmetric axial stretching) at 1300$1000 \mathrm{~cm}^{-1}$ [26]. The fingerprint region which lies from $1500-900 \mathrm{~cm}^{-1}$ is the main spectrum region that allows for distinction between oil and its respective fatty acid alkyl ester [27]. There are marked absorptions at $900 \mathrm{~cm}^{-1}$ and $1050 \mathrm{~cm}^{-1}$ in the spectra of the biodiesels which are absent in the oil spectrum. The peak around $900 \mathrm{~cm}^{-1}$ is assigned to asymmetric stretching of $-\mathrm{CH}_{3}$ while the peak at $1050 \mathrm{~cm}^{-1}$ is considered to be due to asymmetric axial stretching vibrations of $\mathrm{O}-\mathrm{C}-\mathrm{C}$ bonds.

Table 4. Comparative FT-IR peaks of Vitex doniana seed oil and biodiesels.

\begin{tabular}{|c|c|c|c|}
\hline \multirow{2}{*}{$\begin{array}{l}\text { Peak } \\
\left(\mathrm{cm}^{-1}\right)\end{array}$} & \multicolumn{3}{|c|}{ Functional group } \\
\hline & Oil & Biodiesel produced with methoxide & Biodiesel produced with ethoxide \\
\hline 2900 & C-H (stretching) & $\mathrm{C}-\mathrm{H}$ (stretching) & C-H (stretching) \\
\hline 1750 & $\mathrm{C}=\mathrm{O}$ (esters) & $\mathrm{C}=\mathrm{O}$ (esters) & $\mathrm{C}=\mathrm{O}$ (esters) \\
\hline 1485 & $\mathrm{CH}_{2}$ (bending) & $\mathrm{CH}_{2}$ (bending) & $\mathrm{CH}_{2}$ (bending) \\
\hline 1050 & & O-C-C (asymmetric axial stretching) & O-C-C (asymmetric axial stretching) \\
\hline 900 & & $-\mathrm{CH}_{3}$ (asymmetric stretching) & $-\mathrm{CH}_{3}$ (asymmetric stretching) \\
\hline
\end{tabular}

\section{CONCLUSION}

The results showed successful transesterification of oil from Vitex doniana seeds. The seeds which are considered waste have $18.5 \%$ oil and can serve as alternative feedstock for biodiesel since the biodiesel conversion percentage is in excess of $95 \%$. The biodiesels produced from Vitex doniana seed oil can be blended with petrodiesel in different ratios (B5, B10 or B20).

\section{REFERENCES}

1. International Energy Agency, World Energy Outlook. Available at https://www.iea.org/weo2017/2017, Retrieved on 07/06/2019.

2. Enerdata. Available at https://yearbook.enerdata.net/renewables/renewable-inelectricityproduction-share.html2018, Retrieved on 07/06/2019.

3. Jiang, Z.; Xiao, T.; Kuznetsov, V.L.; Edward, P.P. Turning carbon dioxide into fuel. Philos. Trans. Royal Soc. 2010, 368, 3343-3364.

4. Demirbas, A. Theoretical heating values and impacts of pure compounds and fuels. Energy Sources, Part A 2006, 28, 459-467.

5. Iloamaeke, I.M.; Onuigbo, C.C.; Umedum, I.N.; Umeobika, C.U.; Oforah, P.U. Production and characterization of biodiesel from the seed of Dacryodes edulis (African pear). Int. J. Curr. Res. 2016, 8, 25230-25234.

6. Demshemino, S.I.; O'Donnell, P.S.; Muhammad, F.Y.; Nwadike, I.; Okoro, L.N. Comparative analysis of biodiesel and petroleum diesel. Int. J. Educ. Res. 2013, 1, 2-5.

7. US Energy Information Administration. Biofuels Explained; Use of Biodiesel, 2019. Retrieved from https:/www.eia.gov/energyexplained/biofuels/use-of-biodiesel.php. Retrieved on 12/12/2019.

8. US Department of Energy. Alternative Fuels Data Center, 2019. Retrieved from Energy Efficiency and Renewable Energy: https://afdc.energy.gov/fuels/biodiesel_blends.html.

9. Vandkata, R.M.; Mallikarjun, M.V.; Rao, G.L.N. Biodiesel production from palm oil by transesterification method. Int. J. Curr. Res. 2012, 4, 083-088.

10. Orwa, C.; Mutua, A.; Kindt, R.; Jamnadass, R.; Anthony, S. Agroforestree Database: A tree reference and selection guide version 4.0 Available at http://www.worldagroforestry.org/treedb/AFTPDFS/Vitex_doniana.PDF, 2009. 
11. Schmidt, L.H. Guide to handling of tropical and subtropical forest seed. Danida Forest Seed Centre, Humlebaek, Denmark, 532, 2000.

12. Bolanle, J.D.; Adetoro, K.O.; Balarabe, S.A.; Adeyemi, O.O. Hepatocurative potential of Vitex doniana root bark, stem bark and leaves extracts against $\mathrm{CCl}_{4}$-induced liver damage in rats. Asian Pacific J. Trop. Biomed. 2014, 4, 480-485.

13. Egbekun, M.K.; Akowe, J.I.; Ede, R.J. Physico-chemical properties and sensory properties of formulated syrup from black-plum (Vitex doniana) fruit. Plant Foods Human Nutr. 1996, 49, 301-306.

14. Adelodun S.T.; Adewole, O.S.; Bejide, R.A.; Adeyemi, D.O.; Arayombo, B.E; Saka, O.S.; Olayode, A.A. Protective effects of Vitex doniana (black plum) against ischemic testes torsion injury: Histological and morphometric features. J. Int. Soc. Pathophysiol. 2016, 23, 157-168.

15. British Standards. EN 14214:2008 + A1:2009. Automotive fuels - fatty acid methyl esters (FAME) for diesel engines - Requirements and test methods, 2010.

16. Plant for a Future Organization, 2012. Available at https://pfaf.org/user/Plant.aspx?LatinName=Vitex+doniana 1996-2012.

17. Ndukwe, G.I.; Ojinnaka, C.M.; Oyedeji, A.O. Novel bioactive triterpenoid saponin from the fruits of Napoleonaea imperialis P. Beauv (Lecythidaceae). Int. J. Chem. Stud. 2016, 4, 8087.

18. American Society for Testing and Materials (ASTM) International. Annual Book of ASTM Standards. Volume 00.01, Section 5, 2010.

19. AOAC. Official Methods of Analysis of the Association of Official Analytical Chemists. Chapman and Hall Publisher, Washington DC, USA, $24^{\text {th }}$ Edition, 2008.

20. Ajiwe, V.I.E; Ajibola, I.V.O; Martins, C.M.A.O. Biodiesel fuels from palm oil, palm oil methylester and ester-diesel blends. Bull. Chem. Soc. Ethiop. 2003, 17, 19-26.

21. Putri, E.M.M.; Rachimoellah, M.; Santoso, N.; Pradana, F. Biodiesel production from Kapok seed oil (Ceiba pentandra) through transesterification process by using $\mathrm{CaO}$ as catalyst. Global J. Res. Eng. Chem. Eng. 2012, 12(2), Version 1.

22. Ezekwe, C.C.; Ajiwe, V. The variations of physicochemical properties of biodiesel blends with the blend ratios. Int. J. Sci. Innov. Discov. 2014, 4, 11-14.

23. Ibeto, C.N.; Ofoefule, A.U.; Ezeugwu, H.C. Fuel quality assessment of biodiesel produced from ground nut oil (Arachis hypogea) and its blend with petroleum diesel. Am. J. Food Technol. 2011, 6, 798-803.

24. Yunus, M.M.; Zuru, A.A.; Faruq, U.Z.; Aliero, A.A. Assessment of physicochemical properties of biodiesel from African grapes. Nig. J. Basic Appl. Sci. 2013, 21, 127-129.

25. Altun, S. Effect of the degree of unsaturation of biodiesel fuels on the exhaust emissions of a diesel power generator. Fuel. 2014, 117, 450-457.

26. Tariq, M.; Ali, S.; Ahmad, F.; Ahmad, M.; Zafar, M.; Khalid, N.; Khan, M.A.; Identification, FT-IR, NMR $\left({ }^{1} \mathrm{H}\right.$ and $\left.{ }^{13} \mathrm{C}\right)$ and GC/MS studies of fatty acid methyl esters in biodiesel from rocket seed oil. Fuel Process. Technol. 2011, 92, 336-341.

27. Sabrina, N.R.; Vany, P.F.; Leandro, S.O.; Adriana, S.F. FTIR analysis for quantification of fatty acid methyl esters in biodiesel produced by microwave assisted transesterification. Int. J. Environ. Sci. Dev. 2015, 6, 964-969. 